\title{
DIRECT HEAT ENERGY CONVERSION INTO ELECTRICAL ENERGY: AN EXPERIMENTAL STUDY
}

\author{
Vladimir Yezhov* \\ Southwest State University, Kursk, Russia \\ Sergey Yemelianov \\ Rector, Southwest State University, Kursk, Russia \\ Natalia Semicheva \\ Southwest State University, Kursk, Russia \\ Sergey Berezin \\ Southwest State University, Kursk, Russia \\ Alexey Burtsev \\ Southwest State University, Kursk, Russia \\ Valeria Tolmachyova \\ Southwest State University, Kursk, Russia
}

The paper presents some results of experimental studies of the co-generation of heat and electric energy in the process of an injection gas burner operation due to thermoelectric effect utilization. It also contains a description of the used laboratory installation and presents experiment methods. The authors prove the possibility to use consumer gas burners for electricity generation.

Key words: Thermoelectricity, Thermoelectric effect, Re-cycling, Energy, lectric generator, Low potential

\section{INTRODUCTION}

In today's Russia the issues of energy saving and environmental safety are still very important. Efficient solutions of the above problems be found in the housing and public utility sector are able to decrease the cost of heat and electricity, improve environment, personal and social safety.

As a rule, energy saving measures in buildings are intended to reduce irrational heat loss through the building envelope [08, 06] and ventilation emissions $[11,16]$. Also, reducing energy consumption can be achieved by additional energy generation from renewable sources, switching to use of which reduces the impact on environment $[02,17]$.

We believe that the co-generation of electricity and heat that is physically based on Seebeck effect based on is an up-and-coming energy saving trend. Seebeck effect is such thermoelectric effect when thermoemf develops under heat treatment of the contact (junction seam) between two different metals of semiconductors (thermocouple). Thermoedf voltage ET.emf is di- rectly proportional to Seebeck coefficient $\alpha$ and temperature drop $\Delta T$ between the hot $T h$ and cold Tc sides (ends) of the TEM cell. Thermoelectric generation is one of the most promising methods, sometimes it is the only possible way of direct conversion of heat energy into electricity. One of its notable advantages is complete absence of any intermediate links like in the operation of a thermal or nuclear power plant where heat energy is first converted into mechanical energy and then mechanical energy is converted into electricity $[05,12]$.

\section{BURNER-AND-POWER GENERATOR FOR DIRECT CONVERSION OF HEAT ENERGY INTO ELECTRICITY}

Direct conversion of heat into electricity may be very attractive for the Russian Federation that has vast areas (North, Siberia, Far East) that are hard to supply with electricity from permanent sources both financially and technically. More over this electricity generation method can be used in all places where main gas supply and 
gas distribution pipelines are operating, in municipal gas supply lines, in recycling low-potential heat of flue gases, ventilation releases, effluents, etc.

In order to verify this method experimentally a laboratory installation was designed. Its principle design components are a consumer gas burner and a thermoelectric cell that comprises a zigzag row of bare wire sections made from Chromel and Copel and soldered at the ends [03]. The materials (Chromel and Copel - M1 and M2) for thermoelectric converters were chosen because of their availability and low cost. This experimental installation is schematically shown in Figure 1.
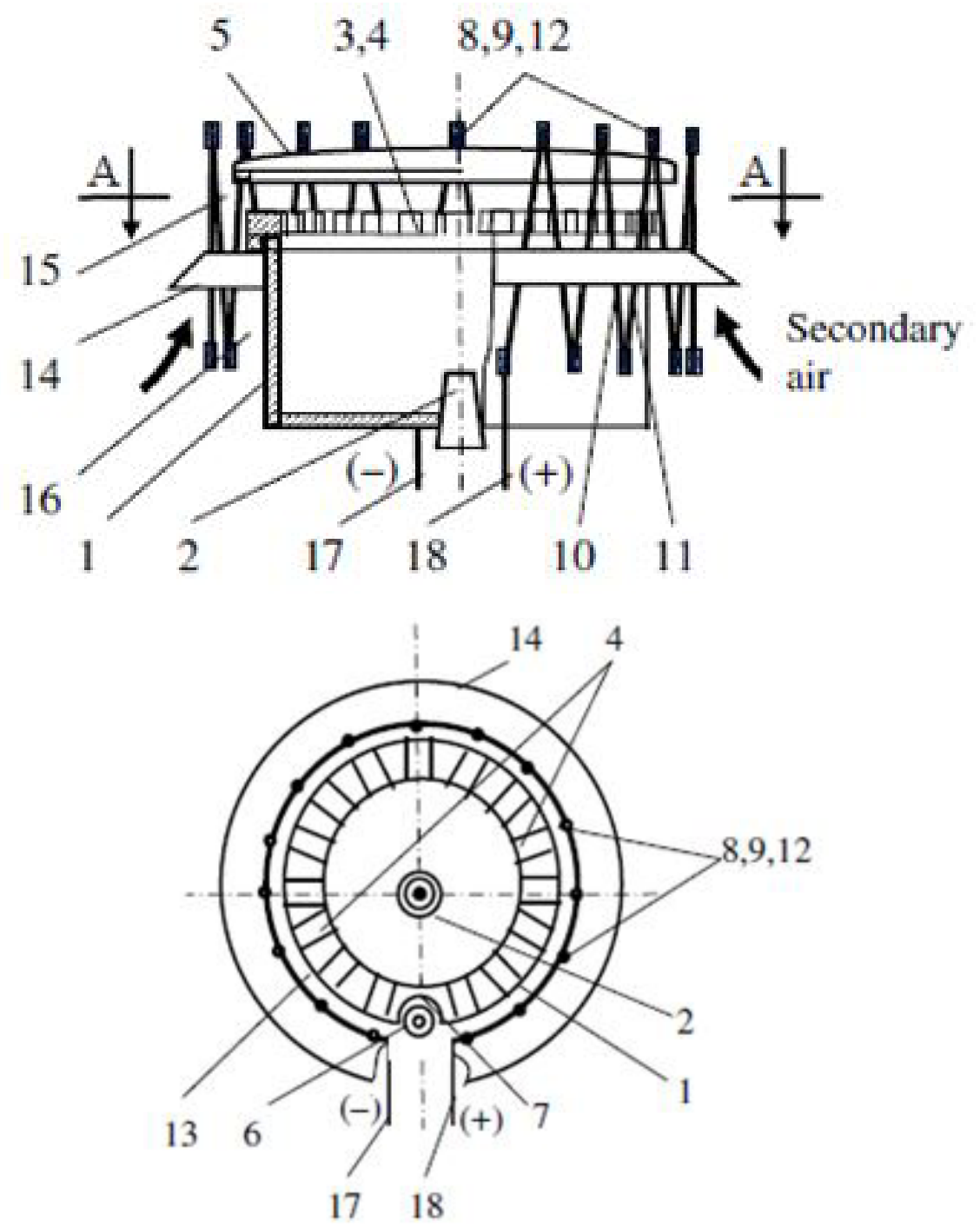

A-A

Figure 1: Experimental installation gas burner - generator: 1 - case; 2 - gas nozzle; 3 - toothed ring disk; 4 - radial grooves (flame ducts); 5 - upper lid; 6 - spark plug; 7 - vertical groove; 8 - thermoelectric cell (TEM cell); 9 - thermo-emission converter (TEMC) ; 10, 11 - sections made from different metals M1 and M2; 12

- zigzag row; 13 - ring duct; 14 - ring screen; 15,16 - hot and cold zones; 17,18 - current terminals.

The basic principle of a gas burner-electric generator is as follows. As the thermoelectric cell (TEM cell) 8 has a shape of a zigzag row 12 made from twin wire sections 10 and 11 that are made from different metals $\mathrm{M} 1$ and $\mathrm{M} 2$ that are soldered (welded) at their ends, then when one side of the soldered ends of wire sections 10 and 11 of thermo-emission converters (TEMC) 9 is heated at the flame base close to the lid 5 (hot zone 15) and the 266 opposite sides of the soldered ends of TEMC 9 that are located in the cold zone 16 are cooled down close to the case bottom 1 , there is a temperature drop between two opposite sides of twin wire sections 10 and 11, which causes thermal emission of electrons in the area of the contact between metals M1 and M2 (their seam line), and that results in the generation of thermal electricity in the zigzag rows 12 of TEM cells 8 [07, p. 502-506]. 
Gas burner - generator operates as follows. Primary air is sucked in above the working surface of the plate through the gap (not shown in Figure 1) between the case 1 and the disk ring 3 . The case 1 is mated with the injector 2 through which gas is supplied, while the primary air is mainly sucked into the burner disk ring due to the friction with the gas jet. As the burner disk ring 3 has many circumferential radial grooves 4 (flame ducts), air-gas mixture ignited by spark plug 2 goes outwards in the radial direction and forms a ring-shaped flame. The lid 5 covers the burner from above and together with the burner ring disk 3 determines the size of flame ducts 4 .

To make the flame steady and improve burning quality the case 1 is furnished with a ring duct 13 that is formed by the zigzag row 12 of TEMC 9 of the TEM cell 8 and the ring screen 14. Going through this duct warmed up secondary air is sucked from the cold zone 16 into the hot zone 15 to go further into the burning zone. Simultaneously this air cools down the bottom soldered ends of TEMC 9 of the TEM cell 8 in the cold zone 16. At the same time when one side of the soldered ends of wire sections 10 and 11 of TEMC 9 are heated at the flame base close to the lid 5 (in the hot zone 15) and the other side of soldered ends of TEMC 9 that are located in the cold zone 16 close to the plate surface (not shown in Fig. 1) are cooled down, the opposite soldered joints of twin wire sections 10 and 11 will have different temperatures and in the area of contact between metals M1 and M2 (soldered seam) thermal emission of electrons will take place, which results in the production of thermal electricity in the zigzag rows 12 of TEM cell 8. Passing through the current terminals 17 and 18 of the zigzag row in each TEM cell 8 the generated electricity is supplied first to the collectors with like charges and then to the converters (not shown in Figure 1) where it gets the desired voltage and current strength to be supplied to the consumers.

\section{EXPERIMENT RESULTS}

The following equipment and conditions were used in the lab experiment:

1. Consumer injection burner - 1 piece

2. Pyrometer (high-precision noncontact IR thermometer) AR 872A (measuring range $180 \mathrm{C}-15000 \mathrm{C})-1$ piece

3. Thermoelectrical cell (TEM cell) -1 piece

4. Engineering data of a TEM cell 8: number of TEMC 9 in a TEM cell $8=100$ pcs.; length of wire sections $10,11(M 1, M 2)=80$ $\mathrm{mm}$; diameter of wire sections $10,11=0.6$ $\mathrm{mm}$;

5. Fuel data: natural gas source was portable gas accumulator containing gas mixture of $70 \%$ butane and $30 \%$ propane, QPR $=94800 \mathrm{~kJ} / \mathrm{m} 3$;

6. Experiment conditions: external air temperature was $200 \mathrm{C}$. Heat load was regulated by gas flow rate.

Experiment results are given in Table 1 and Figures. 2 and 3.

Table1. Experiment results

\begin{tabular}{|c|c||c|c|c|c|c|}
\hline № & $\begin{array}{c}\text { Hot soldered } \\
\text { joint tempera- } \\
\text { ture (Th), OC }\end{array}$ & $\begin{array}{c}\text { Cold soldered } \\
\text { joint tempera- } \\
\text { ture (Tc), OC }\end{array}$ & $\begin{array}{c}\text { Temperature } \\
\text { drop }(\Delta \mathrm{T}), 0 \mathrm{C}\end{array}$ & $\begin{array}{c}\text { Voltage, } \\
\mathrm{V}\end{array}$ & $\begin{array}{c}\text { Current strength, } \\
\mathrm{mA}\end{array}$ & $\begin{array}{c}\text { Power, } \\
\mathrm{W}\end{array}$ \\
\hline 1 & 2 & 3 & 4 & 5 & 6 & 7 \\
\hline 1 & 400 & 46 & 354 & 2.1 & 50 & 0.105 \\
\hline 2 & 455 & 46 & 409 & 2.3 & 65 & 0.150 \\
\hline 3 & 505 & 47 & 458 & 2.7 & 80 & 0.194 \\
\hline 4 & 555 & 47 & 508 & 3.0 & 90 & 0.270 \\
\hline 5 & 600 & 47 & 55 & 3.3 & 100 & 0.330 \\
\hline 6 & 650 & 47 & 603 & 3.5 & 120 & 0.410 \\
\hline 7 & 705 & 48 & 657 & 3.9 & 150 & 0.593 \\
\hline 8 & 750 & 48 & 702 & 4.2 & 160 & 0.672 \\
\hline 9 & 805 & 48 & 757 & 4.6 & 170 & 0.795 \\
\hline 10 & 850 & 49 & 801 & 4.8 & 180 & 0.860 \\
\hline 11 & 900 & 50 & 850 & 5.1 & 200 & 1.020 \\
\hline
\end{tabular}




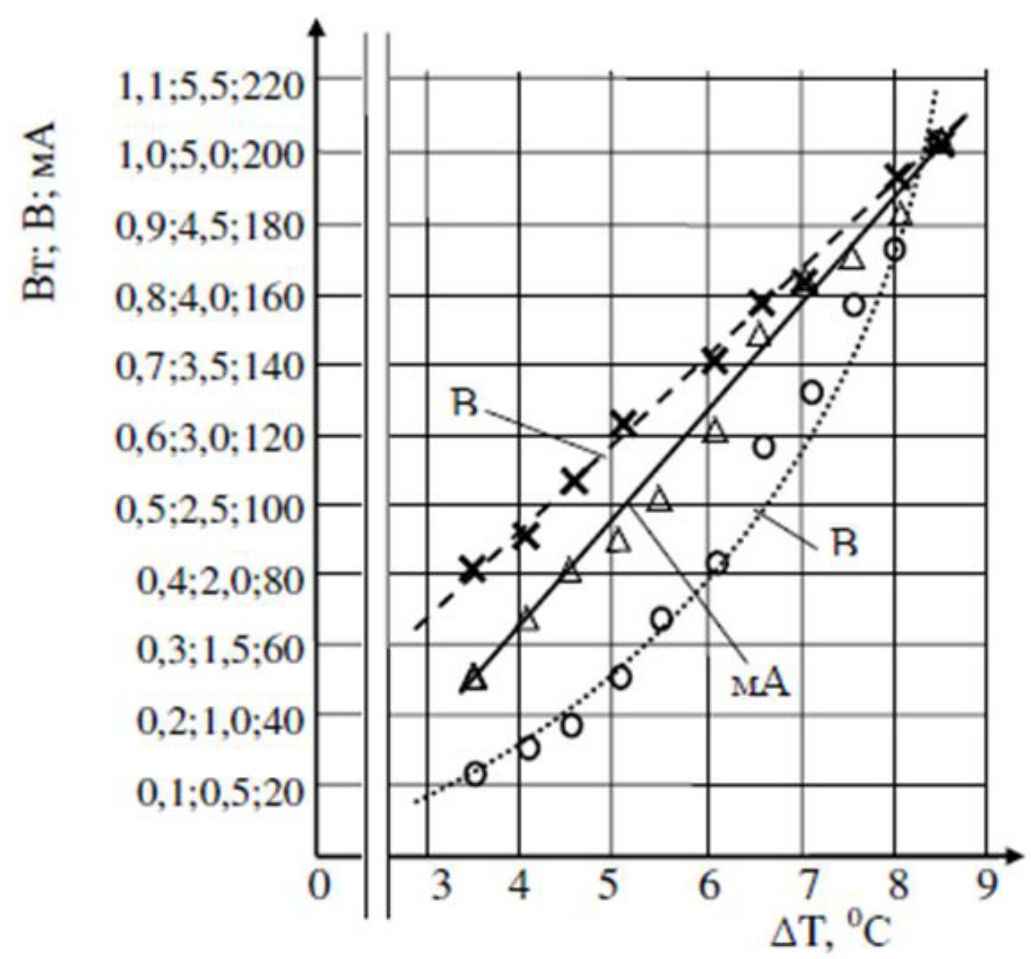

Figure 2: A curve of power $(W)$, voltage $(V)$ and current strength $(m A)$ dependence on the temperature drop value $(\Delta T)$ : o - power; $x$ - voltage; $\Delta$ - current strength - experimental data

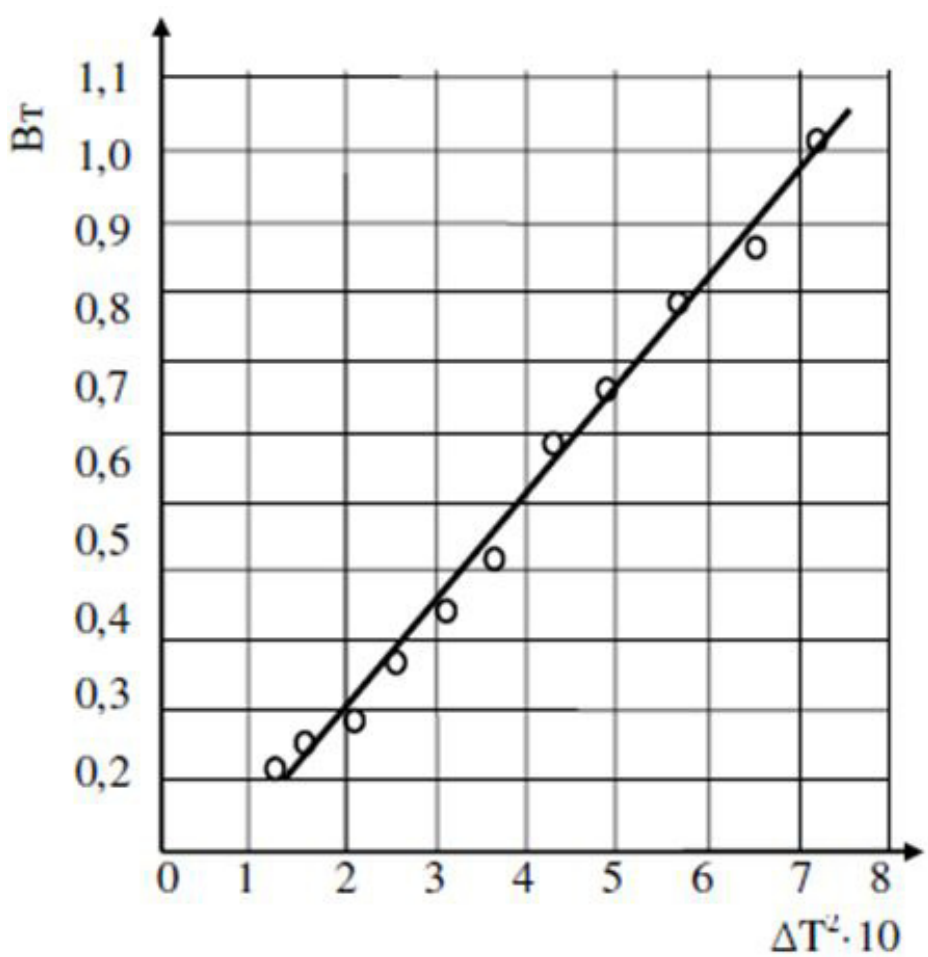

Figure 3: A curve of electric power $(W)$ dependence on squared temperature difference $\left(\Delta T^{2}\right)$ : 0 - power that was found by experimental data

An example of the device for heat and electricity co-generation is a thermoelectric generator for individual power supply. Such generator has heat exchanging surface configured from TEMCs [19] (Figure 4). 

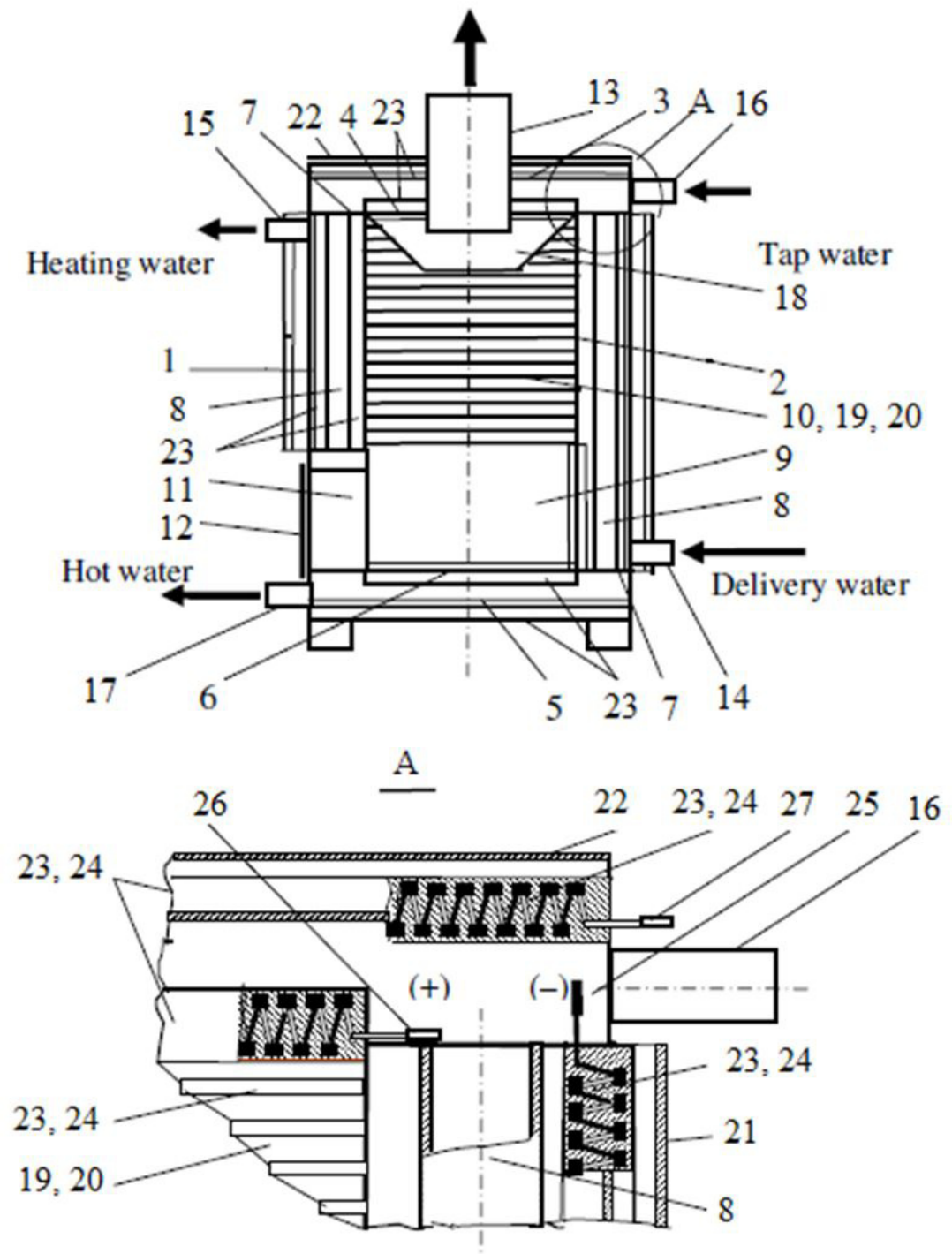

Figure 4: Thermoelectric generator for individual power supply: 1,2 - cases; 3,4-hoods; 5,6 - bottoms; 7 - cross-cut gas-tight partition plates; 8 - vertical piping; 9 - furnace; 10 - gas flue; 11 - charging opening; 12 - hatch; 13 - gas pipe; 14, 15 and 16, 17 - inlet and outlet branch pipes; 18 -gas-collecting main; 19 - plate heat exchanger; 20 - vertical partitions; 21 - decorative casing; 22 - П-shape decorative cover; 23, 24 - fins (TEM cell); 25 - soldered joints; 26, 27 - terminals.

\section{CONCLUSIONS}

Research results have demonstrated that to generate electric energy as a by-product of heat generation in injection burners thermo-emission converters (TEMC) can be used as a main design component, with these converters consisting of twin wire sections made from two different metals: M1-Chromel and M2 - Copel. Largescale use of these metals in thermo-generators is able to reduce the production cost of these appliances and increase their reliability.

\section{REFERENCES}

1) Alihodzic, R., Murgul, V., Vatin, N., Aronova, E., Nikolic, V., Tanić, M., Stanković, D. (2014): Renewable Energy Sources used to Supply Pre-school Facilities with Energy in Different Weather Conditions, Applied Mechanics and Materials, Vol. 624, pp. 604-612.

2) Aronova, E., Radovic, G., Murgul, V., Vatin, N. (2014): Solar Power Opportunities in Northern Cities (Case Study of Saint-Petersburg), Applied Mechanics and Materials, Vols. 587-589, pp. 348-354.

3) Ezhov V.S., Berezin, S.V., Berezin D.S. (2015): Zajavka na izobretenie RF № 
2015119415, Gorelka-jelektrogenerator.

4) Ezhov V.S., Semicheva N.E., Kosinov A.V., Lysenko I.V., Pivovarov A.S. (2015): Patent RF №2541799 Teplojelektricheskij generator dlja individual'nogo jenergosnabzhenija, Bjul. 5, 13 p.

5) Ezhov, V.S., Semicheva, N.E. (2012): Ispol'zovanie nizkopotencial'noj teplovoj jenergii dlja jelektrosnabzhenija zdanij, Izvestija Jugo-Zapadnogo gosudarstvennogo universiteta. Serija Tehnika i tehnologii, CHast' 2, № 12, pp. 65-62.

6) Jocovic, M., Melovic, B., Vatin, N., Murgul, V. (2014): Modern business strategy Customer Relationship Management in the area of civil engineering, Applied Mechanics and Materials, Vol. 678, pp 644-647.

7) Kalashnikov S.G. (1970) Jelektrichestvo, Komsomolsk-na-Amure: Bukinist, 668 p.

8) Milajić, A., Beljaković, D., Davidović, N., Vatin, N., Murgul, V. (2015): Using the Big Bang - Big crunch algorithm for rational design of an energy-plus building, Procedia Engineering, Vol. 117, pp. 911-918.

9) Murgul, V. (2014): Solar energy systems in the reconstruction of heritage historical buildings of the northern towns (for example Sankt-Petersburg), Journal of Applied Engineering Science, Vol. 12 (2), pp. 121-128.

10) Murgul, V., Vuksanovic, D., Vatin, N., Pukhkal V. (2014): The use of decentralized ventilation systems with heat recovery in the historical buildings of St. Petersburg, Applied Mechanics and Materials, Vols. 635-637, pp. 370-376.

11) Murgul, V., Vuksanovic, D., Vatin, N., Pukhkal, V. (2014): Decentralized ventilation systems with exhaust air heat recovery in the case of residential buildings, Applied Mechanics and Materials, Vol. 680, pp. 524-528.

12) Ohotin A. S., Efremov A. A., Ohotin V. S., PushkarskijA. S. (1971) Termojelektricheskie generatory, Moscow: Atomizdat, 292 p.

13) Pukhkal, V., Murgul, V., Garifullin, M. (2015): Reconstruction of buildings with a superstructure mansard: options to reduce energy intensity of buildings, Procedia Engineering, Vol. 117, pp. 624-627.

14) Pukhkal, V., Tanić, M., Vatin, N., Murgul, V. (2015): Studying humidity conditions in the design of building envelopes of "Passive House" (in the case of Serbia), Procedia Engineering, Vol. 117, pp. 859-864.

15) Pukhkal, V., Vatin, N. , Murgul, V. (2014): Central ventilation system with heat recovery as one of the measures to upgrade energy efficiency of historic buildings, Applied Mechanics and Materials, Vols. 633-634, pp. 1077-1081.

16) Pukhkal, V., Vatin, N. , Murgul, V. (2014): Centralized natural exhaust ventilation systems use in multi-story residential buildings, Applied Mechanics and Materials, Vol. 680, pp. 529-533.

17) Radovic, G., Murgul, V., Cvetkovska, M., Aronova, E., Vatin, N. (2014): Solar power supply for remote objects of historical heritage in Montenegro, Journal of Applied Engineering Science, Vol. 12 (4), pp. $277-284$.

18) Radovic, G., Murgul, V., Vatin, N., Aronova, E. (2014): Hybrid Photovoltaic-diesel Energy System Optimization (Case Study of Electric Power Supply for Buildings under the Weather Conditions of Montenegro), Applied Mechanics and Materials, Vol. 627, pp. 357-364.

19) Zadvinskaya T.O., Gorshkov A.S. (2014): Comprehensive method of energy efficiency of residential house. Advanced Materials Research. Vol. 953-954. pp. 1570-1577.

Paper sent to revision: 11.02.2015.

Paper ready for publication: 14.12.2015. 